\title{
Life Skills Education in Kenya: An Assessment of the Level of Preparedness of Teachers and School Managers in Implementing Life Skills Education in Trans- Nzoia District, Kenya
}

\author{
Francis $\mathrm{ABOBO}^{1}$, John Aluko ORODHO ${ }^{2}$, \\ Doctorate Student, Department of Educational Management, Policy and Curriculum Studies, School of \\ Education, Kenyatta University, Kenya \\ Associate Professor, Department of Educational Management, Policy and Curriculum Studies, School of \\ Education, Kenyatta University, Kenya
}

\begin{abstract}
Though Life Skills Education (LSE) has been made a compulsory component of basic education by the Ministry of Education in Kenya, effective teaching is hampered by several factors. The purpose of this study was to investigate the level of preparedness by teachers and school managers in implementing the Life Skills Education in secondary schools in Trans-Nzoia West District. To achieve this purpose, the study was guided by three fold objectives, namely) to determine teachers' training on LSE, ii) find out teachers' and students attitudes towards implementation of LSE in secondary schools, and iii) to establish the level of availability and adequacy of teaching/learning resources for implementing LSE in secondary schools. A descriptive survey design was used for the study. From the target population of 1800 students, 150 teachers and 37 principals in 37 public secondary schools in the district, stratified random sampling technique was adopted to draw 15 principals, 30 teachers and 180 students yielding 225 subjects. Questionnaires were used to collect data from teachers and students while interview schedules were used to collect data from the principals. Quantitative data from questionnaires were analyzed using Statistical Package for Social Sciences (SPSS) while qualitative data from interviews were analyzed thematically. The main findings were that: most teachers had not been trained on Life Skills Education hence indicating low level of preparedness by teachers. It was established that while teachers had negative attitude towards teaching of LSE, students portrayed a positive attitude towards learning of LSE. Regarding the level of availability and adequacy of teaching and learning resources, the study found that although the critical teaching/learning resources were available, they were grossly inadequate in most secondary schools studied. It was concluded that the level of preparedness by teachers and school managers was fairly low and this hampered effective implementation of the educational component in schools visited. It was recommended that teachers should be trained on Life Skills and appropriate instructional resources put in place to facilitate effective implementation of life skills not in the study locale, but also in other schools in the county with similar experiences. [345 words]
\end{abstract}

Keywords: Life skills education, Implementation, level of preparedness, teachers, school managers, Secondary schools, Trans-Nzoia District, Kenya.

\section{Background to the Study}

\section{Introduction}

In studies on Life Skills Education in globally, what tends to emerge is that there is as yet no consensus on the conceptualization of the term life skills education (Cronin,1996; Parson,et.al.,1988; Orodho, Waweru, Ndichu \& Nthinguri , 2013; Republic of Kenya/UNESCO,2012;UNICEF,1999,2002; UNESCO,2012; WHO ,1997), and this makes the implementation of the education component rather complex. Cronin (1996) defines Life Skills as those skills or tasks that contribute to the successful, independent functioning of a person in adulthood. These skills may generally be grouped in five broad clusters: self-care and domestic living, recreation and leisure, communication and social skills, vocational skills, and other skills vital for community participation. The WHO (1997) defines Life Skills, as abilities for adaptive and positive behaviour that enable persons to deal effectively with the demands and challenges of everyday life. Based on this definition, a working definition was formed for South East Asia Region (SEAR) countries on Life Skills as abilities for adaptive and positive behaviour that enable them to deal effectively with the demands and challenges within the family, community and cultural context (WHO, 2001). According to UNICEF (2002) definition of life skills, Life Skills include cognitive skills, practical skills, person's positive behaviour that enable persons to deal effectively with the demands and challenges of everyday life. Life Skills are psycho-social skills including problem-solving and critical thinking skills, personal skills such as self-awareness, and interpersonal skills. Possessing life skills means having qualities such as high self-esteem, sociability, tolerance, action competencies to generate change, 
capabilities to have the freedom to decide what to do and who to be (UNCEF, 1999).

The lack of consensus on the concept of life skills notwithstanding, Education for All (EFA) goal three (3) stresses the need to ensure that the learning needs of all young people and adults are met through equitable access to appropriate learning and life skills ( Republic of Kenya,2012). Coincidentally, the Republic of Kenya in collaboration during the end of decade evaluation (EDA) of the achievement of EFA goals in 2012 conceded that this goal remains a difficult area to conceptualize and measure due to the complex nature of life skills and lifelong learning and the fact that quantitative benchmarks for these programmes are not yet well defined nationally and internationally (Republic of Kenya/UNESCO, 2012). As a consequence of this complex scenario, while assessing the achievement of EFA in Kenya, the evaluating team focused on three life skills areas, namely: HIV and AIDS Education, Peace Education, and Technical Industrial and Vocational Education and Training (TIVET). In making this focus, Republic of Kenya/UNESCO (2012) justified the choice of focus by arguing that the three areas were critical in enhancing the socio-economic development of the country in the wake of rising HIV infections, recent challenges to social cohesion, and high unemployment rate. The evaluation team went further to lament that in the absence of policy frameworks, and elaborate curricular and programmes that addresses life skills issues holistically, a shared understanding of this concept across formal, non-formal and informal education in Kenya is lacking. It is against this backdrop that this study made a spirited attempt to examine the level of preparedness of teachers and school managers in implementing life skills education in secondary schools in Tran-Nzoia District, Kenya,

\section{The State of the Art Review}

There is a growing body of literature on preparedness to implement curriculum which touches on a wide range of areas including teacher training, attitudes of the teacher and learner and availability and/or adequacy of instructional resources, especially with regard to implementation Life Skills Education (Bizimana \& Orodho, 2014; Bunyi, 2000; Jansen, 2008; Krilik, 2008; Orodho, 2013; Orodho, Waweru, Getange \& Miriti,2013; Republic of Kenya/UNESCO, 2012). In reviewing literature along these lines, it is instructive to be cognizant of the genesis of life skills education in Kenya to help understand the issues related to its implementation.

The government of Kenya introduced the teaching of Life Skills Education as non-examinable subject in secondary schools in 2008 with the intention to empower students with psychosocial competencies that would help them make informed decisions, solve problems, think creatively and critically, communicate effectively, build health relationships, empathize with those in need and manage their life in a healthy and productive manner including the fight against HIV and AIDS infections( Republic of Kenya,2012a,2012b) . It is a comprehensive behaviour change approach that concentrates on the development of the psychosocial skills needed for life. The course goes beyond providing information to the development of the whole individual. One of the benefits of Life Skills Education is that the topics covered are adaptable to many different contexts (Republic of Kenya, 2008; KIE, 2008).

Literature is prolific which provides factors that influence curriculum implementation (Bizimana \& Orodho, 2014; Oluoch, 1982; Shiundu \& Omulando; Orodho, 2014). According to Oluoch (1982) and Shiundu and Omulando (1992), one of the factors in curriculum implementation is the pre -service and in-service training of teachers, pre-service is the training of teachers on a certain curriculum before they start teaching while inservice is the training of teachers on how to implement a certain curriculum while they are already in the field. Given their vital role in curriculum implementation, teachers need appropriate relevant training to be able to handle a new programme including life skills education. This study therefore, sought to find out if training of teachers affects the implementation of life skills education in secondary schools.

Students also play a crucial role in the successful implementation of a curriculum innovation. Just as teachers, students must accept a curriculum for it to be effective (Ornstein \& Hunkins, 1993; Orodho, 2013). It is when students react to the experiences they encounter in the curriculum with the cooperation, that a successful implementation of a curriculum can be achieved at classroom level. If these students see little relevance in the curriculum activities taught, they are not going to be motivated to participate to learn (Orodho, 2013).

It is the teacher who finally decides the arrangement of learning experiences and the methods of content presentation and he/she does most of the evaluation. It is the teacher therefore, who initiates, develops and directs students' learning. Therefore, a teacher who has a positive attitude towards Life Skills education and uses appropriate instructional strategies is likely to influence the students develop the same attitude (Oluoch, 1982; Omulando and Shiundu, 1992). This study therefore, sought to find out if students' and teachers' attitude affect the implementation of life skills education in secondary schools.

The life skills education syllabus and the Teachers' Guide suggest that teachers use participatory teaching and learning methods in which learners identify their own problems, discuss solutions, plan and carry out effective action programmed ( Republic of Kenya, 2006). The participatory teaching and learning methods 
assume that learning is best achieved by requiring learners to be actively involved during lessons. The participatory teaching and learning methods recommended for the teaching of life skills education include teaching strategies such as case studies, brainstorming, field visits, panel discussions, story-telling, songs group discussion, debate, posters, role-play, games, projects, poetry-recitals and drama. This study therefore, sought to analyze on teaching strategies and if they affect the implementation of life skills education in secondary schools.

Literature on the teaching of life skills education suggest that the subject is different from other subjects in that it is particularly concerned with teaching of values. Values are however not learned as other curriculum subjects. Values are better taught by living them. The question which the subject raises is whether values can be taught, and if so, whether it should be the role of schools to effectively teach them. In answering this question, Bunyi (2000) asserts that aspects of values are not found in books or documents but learned through social interactions in day-to-day life, hence they should be practiced. Students need to be aware of and fully understand the fact that classes on life skills education are different from other subjects in the school curriculum. Krilik (2008) argues that "values are learned as they do not pass from parents to children in the form of DNA". Students learn values through observing and imitating their teachers' behaviors (Jansen, 2008). Teachers thus need to be role-models of good behavior if they wish their students to develop the desired values. Thus having a subject like life skills education which teaches students what is wrong or right may not be a guarantee that the children are going to behave accordingly. This study therefore, sought to investigate challenges affecting the implementation of life skills education in secondary schools in Trans-Nzoia West District.

\section{Teacher Training}

There are many factors that affect the implementation of a school curriculum. According to Oluoch (1982) and Shiundu and Omulando (1992) and Orodho (2013) concur that, one of the factors in curriculum implementation is the pre -service and in-service training of teachers, pre-service is the training of teachers on a certain curriculum before they start teaching while in-service is the training of teachers on how to implement a certain curriculum while they are already in the field. Given their vital role in curriculum implementation, teachers need appropriate relevant training to be able to handle a new programme including life skills education. Curriculum specialists must utilize the saying that "No education is better than its teachers". It is the teacher who translates the broad general goals into instructional objectives.

Teachers are an important resource in the teaching and learning process and their training and utilization therefore requires critical consideration. The current government programmes for teacher education aim at providing qualified teachers and are, therefore, central to ensuring the provision of quality education. Current teacher training programmes cater for the production of teachers for pre-primary, primary, secondary, special, vocational and technical education. The objectives of teacher education programmes aim at developing communication skills, professional attitudes and values that equip teachers with the knowledge and ability to identify and develop the educational needs of the child (Republic of Kenya/UNESCO, 2012; Republic of Kenya, 2013).

\section{Attitudes towards Teaching of Life Skills in Schools}

The other factor that affects the implementation of any curriculum is attitude. Thurstone (1931) defines attitude as the effect for or against a psychological object. Thurstone proposes that there is need to test people's attitude, these can be accomplished by assessing people's opinions and beliefs which he considers to be verbal expressions of attitudes. In proposes that there is need to test people's attitude, this can be accomplished by assessing people's opinions and beliefs which he considers to be verbal expressions of attitudes. In the implementation of a school curriculum, the teacher's attitude is very important. This is because teaching is an art guided by educational values, personal needs and by a variety of beliefs or generalizations that the teacher holds to be true. The students also play a crucial role in the successful implementation of a curriculum innovation. Just as teachers, students must accept a curriculum for it to be effective (Orodho, Waweru, Getange \& Miriti, 2013). It is when students react to the experiences they encounter in the curriculum with the cooperation, that a successful implementation of a curriculum can be achieved at classroom level. If these students see little relevance in the curriculum activities taught, they are not going to be motivated to participate to learn.

Githinji (2007), on her study, on perceptions of primary school teachers and pupils on adequacy of HIV/AIDS life skills education in Nairobi and Thika Districts, found that there were inadequate teaching, insufficient knowledge and lack of enough life skills education to both teachers and pupils. The study also found that teachers found it difficult to explain and teach some of the ways in which AIDS is spread. They felt that some of HIV/AIDS life skills education teachers lacked training and adequate time, cultural differences, resistance from parents, and lack of support from the administration were other problems that teachers contend with.

Prinsloo (2007), in South Africa found that lack of commitment by some principals to make the 
programmed a success at the school level is a challenge facing the implementation of the life skills education. Some principals indicated that it was difficult for them to support the implementation of life skills education because many learners in their schools are "careless, irresponsible and have no vision or mission in life." The principals felt that there was little impact of life skills education could make on the learners even if the principals provided some support for the teaching of the subject in their schools. The principals' excuse for their lack of commitment to make life skills programmed a success in their schools may be considered as a negative attitude; they were blaming learners for their problems in their schools.

The successful making an implementation of a curriculum depends on the teacher's attitude towards work. In this study teacher's positive attitude means 'teacher's beliefs and interest towards teaching given the conditions of his or her work. (Jansen, 2002). The feeling that a teacher has about his or her work shapes his / her ability in implementing a curriculum policy. Kadzamira (2006), a study notes that low salaries and coupled with other poor working conditions in Malawi cause widespread teacher discontent so teaching is regarded as "employment of last resort." Teachers' discontent with their career may affect the implementation of any curriculum including life skills education. Teacher's positive attitude towards implementing a curriculum depends on teacher's content knowledge of the curriculum. Teachers should understand the goals and content of syllabus well in order to implement it effectively. Teachers who are supposed to implement a new curriculum sometimes cannot even identify its main features. The problem is likely to be encountered when teachers are required to change their educational approaches to teach this new curriculum (Pratt, 1980). Mahlangu, (2001) raises a concern about introducing a curriculum to teachers and leaving them to implement without further guidance.

\section{Availability of Teaching/ Learning Resources}

KIE (2008) assert that resources are valuable possessions used to enhance the teaching/learning process. They may be tangible or intangible, human or non human. In Life Skills Education tangible resources include: material equipment, media and books among others. Intangible resources include time, human skills, energy and knowledge. Resources help in increasing learner's attention span thus making teaching/learning more effective. They make it easy for the students to acquire concepts and skills which enable them to relate to the world around them.

The teacher should determine the best resources for a particular lesson and the resource should be used in the most natural and logical manner known to reinforce a particular learning activity. However, they should compliment teaching and learning and not replace the teacher. Some resources can be bought or sourced from the environment, locally made, borrowed or shared at departmental inter-school levels. The importance of teaching/learning resources is as follows: they make the learning of Life Skills Education interesting, real and enjoyable, they encourage students to retain knowledge, life skills and attitudes learnt, they appeal to some senses such as sight, touch, smell, among others, they make it possible for students understand abstract ideas, and clarify concepts and ideas, and finally they provide stimulus variation in the teaching learning process thus making the lesson captivating (KIE, 2008).

A study by Orodho (2013) conducted in public secondary schools in Kenya demonstrated most schools do not have adequate and appropriate instructional resources that facilitate effective instruction for effective implementation of curriculum. Ina similar study by Birimana and $\operatorname{Orodho}(2013,2014)$ on teaching and learning resource availability and teachers effective classroom management and content delivery in secondary schools in Huye District, in Rwanda, reached a verdict that most of the schools in the study locale had inadequate instructional resources hence compromising the quality of education through poor curriculum implementation strategies. They suggested that teaching and learning resources should be equitable distributed in schools. Birimana and Orodho (2014) argue that besides using teaching materials, teachers must ensure that a variety of the same are availed in class for effective teaching and learning. The materials and equipment presented in the classroom situation should be chosen to provide many and varied opportunities for students to acquire the learning they need. This ensures that students are offered many opportunities to practice and master Life Skills Education through a variety of materials, and hence lead into successful implementation of life skills education.

\section{Statement of the Problem}

Life skills education was introduced in secondary schools in Kenya in 2008 by the MOE. The major reason for its introduction was to equip the students with psychosocial competencies that would help them make informed decisions, solve problems, think creatively and critically, communicate effectively, build health relationships, empathize with those in need and manage their life in a healthy and productive manner including the fight against HIV and AIDS infections. Despite the introduction of life skills education in schools, there are challenges which seem to affect its introduction in secondary schools. These challenges may reduce the possibilities of life skills education achieving the objectives for its implementation, for example, students may 
not acquire skills required to deal effectively with demands and challenges of everyday life. This study therefore, sought to investigate challenges facing implementation of life skills education in secondary schools in Trans-Nzoia West District.

\section{The Purpose and Objectives of the Study}

The purpose of this study was to examine the level of preparedness by teachers and school managers in the implementation of Life Skills Education in secondary schools in Trans-Nzoia West District. The study had three fold objectives, namely:

i) Examine teachers' training on Life Skills Education in secondary schools in Trans-Nzoia West District.

ii) Find out teachers' and students attitude towards implementation of Life Skills Education in secondary schools in Trans-Nzoia West District.

iii) Assess the level of availability and adequacy of teaching/learning resources for implementation of Life Skills Education in secondary schools in Trans-Nzoia West District.

\section{Theoretical Framework}

This study used Social Learning Theory or Social Cognitive Theory (SCT) by Albert Bandura (1986). This theory explains that children learn to behave through both formal instruction (for example how parents, teachers and other authorities and role-models tell them to behave) as well as observation, and for example, as they see adults and peers behaving). The children's behavior is reinforced or modified by consequences of their actions and responses of others to their behaviors. Students learn to behave, through observation and social interaction, rather than just verbal instruction. Similarly students taught skills through process of instruction, rehearsal, and feedback rather than just instruction. Bandura also stressed that self-efficacy, defined as confidence in one's abilities to perform appropriate behavior, is important to learning and maintaining behaviors.

In the school situation for example, social cognitive theory contends that teachers teaching life skills education need to create an appropriate environment where skills teaching need to replicate the natural process by which students learn positive behavior through role-modeling, observation and social interaction. Teachers' reinforcement is important in the teaching/ learning of life skills education and shaping students' behavior. Positive reinforcements by teachers are applied for behaviour skills that need to be adjusted to build more positive actions of students. Teachers are important role-models, standard setters and source of influence so that they need appropriate training to be able to handle life skills education, they also need positive attitude towards life skills education so that they make students develop similar attitudes towards the subject, teachers need to use teaching and learning materials which can effectively implement life skills education and finally use participatory methods in which students identify their own problems, discuss solutions, plan and carry out effective action

\section{Conceptual Framework}

The conceptual framework below shows the relationship between the variables of the study. According to Orodho (2009a, 2012), a conceptual framework is a model of presentation where a researcher represents the relationships between variables in the study and shows the relationship graphically or diagrammatically Figure $1)$.

The dependent variable in this study was the implementation of Life Skills Education in secondary schools while the independent variables were: teaching methods, teacher training, teaching/learning materials, teachers' attitudes and students' attitudes. The independent variables in the study have influence on the dependent variables in that they can lead into effective implementation of Life Skills Education in secondary schools. 


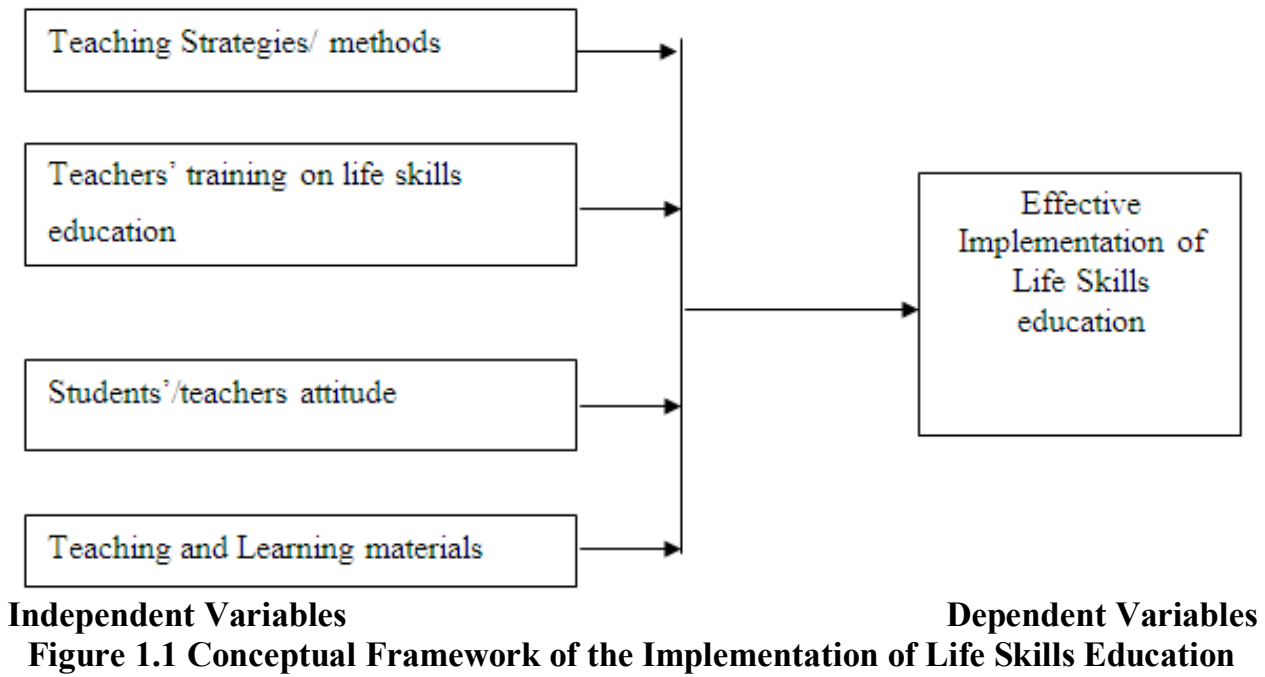

Teachers need appropriate training to be able to handle Life Skills Education in secondary schools, teachers' positive attitude towards teaching of Life Skills Education make their students develop same attitude towards Life Skills Education, teachers also need to use proper teaching and learning aids which leads to successful implementation of Life Skills Education and finally teachers should use participatory methods which make students identify their own problems and hence lead into effective implementation of Life Skills Education in secondary schools.

\section{Research Design}

\section{Research Methodology}

This study used a descriptive survey. The purpose of descriptive survey is basically to observe, describe and document aspects of a situation as they naturally occur hence the choice for the study. The fact that it is not concerned with characteristics of persons, it provides information about population variables. According to Orodho (2009a), a descriptive survey is, a process of collecting data in order to answer questions concerning the current status of the subject. According to Kothari (2003), the main advantage of this type of design is that it enables the researcher to assess the situation within the study area at the time of the study. It was on the basis of these characteristics of descriptive survey that challenges facing implementation of life skills education in secondary schools were investigated. It involved direct observation where the required behaviour was observed in a particular setting. The design was therefore, deemed appropriate as it enabled the researcher to find out the challenges facing implementation of Life Skills Education in secondary schools in Trans-Nzoia West District.

\section{Variables of the Study}

The independent variables of the study were: teaching methods, teacher training, teachers' attitudes and students' attitude. The dependent variable for the study was implementation of Life Skills in secondary schools. The independent variables in the study have influence on the dependent variables in that they can lead into effective implementation of Life Skills Education in secondary schools. Teachers need appropriate training to be able to handle Life Skills Education in secondary schools, teachers' positive attitude towards teaching of Life Skills Education make their students develop same attitude towards Life Skills Education, teachers also need to use proper teaching and learning aids which leads to successful implementation of Life Skills

\section{Target Population and Sample Selection}

The population for the study was public secondary schools in Trans-Nzoia West District. There are 37 secondary schools in the district. This population consisted of 37 principals, 555 teachers and 4173 students totaling to 4765 . The study targeted 37 principals, 150 teachers and 1800 students. Teachers were targeted because they are perceived to be the major agents for curriculum delivery and implementation. Teachers are in direct contact with students and have the responsibility of employing the recommended teaching/learning strategies and are directly involved in the teaching of Life Skills Education. Students from form two to four were targeted in the study because they were perceived to have information on the importance of Life Skills Education and the skills that they have learnt. The researcher left out form one students because they were just reporting at the start of the study. Principals were targeted because they supervise the curriculum implementation in their secondary schools. 
Purposive sampling technique on the basis of type of school and boarding status was used to select 15 schools out of 37 to form the sampling units for respondents. From these 15, 180 students, 30 teachers and 15 principals were yielding a sampled of 225 respondents for the study The entire sampling is displayed in Table 1.

Table 1: Target Population and Sample Selection

\begin{tabular}{lcccc}
$(\mathrm{N}=225)$ & & & \\
\hline Targeted Population & Sample per school & Sample $(\mathbf{N}=\mathbf{1 8 0})$ & Percentage & $\mathbf{( \% )}$ \\
\hline Principals & 1 & 15 & 20 & 100 \\
Teachers & 2 & 30 & 20 & \\
Students & 12 & 180 & 10 & \\
\hline Total & \multicolumn{5}{c}{$\mathbf{2 2 5}$}
\end{tabular}

\section{Research Instruments}

On the basis of the literacy level of the sampled respondents, the researcher concluded that they were able to read and understand the research instruments. The researcher used questionnaires, interview schedules and Observation schedule to collect the data for the study.

\section{Questionnaires for Teachers}

The researcher used questionnaires to collect data from teachers. The instrument was chosen because the sampled respondents were considered learned and they would be able to read and understand the questionnaire items; and therefore the data required for the study were easily extracted. Likert Scale was used for the questions testing on the degree or the extent of the factor under investigation. Wiersma (1980), states that a questionnaire is a list of questions or statements to which the individual is asked to respond in writing. Orodho (2012) further clarifies that a good questionnaire should not only represent the aims of the researchers who send it out, but should also allow for the full variety of possible answers.

\section{Questionnaires for Students}

The researcher used questionnaires to collect data from students. The instrument was chosen because the students were considered literate enough to help them read and understand the questionnaire items which enabled the researcher to get the information required for the study. The instrument contained both open-ended and closed-ended questions. Likert Scale was used for the questions testing on the degree or the extent of the factor under investigation.

\section{Interview Schedules}

Interview schedules were administered to 15 principals of the sampled secondary schools to establish the challenges facing implementation of Life Skills Education in secondary schools. The researchers personally held interviews with the principals participating in the study. Interview guide was meant to provide supplementary data which would not have been captured by the questionnaires. The instrument contained questions on teachers' training on life skills education, teachers' and students attitude towards implementation of life skills education, schools' preparedness in terms of teaching/learning resources and teaching strategies used for teaching life skills education. Yin, (2003) states that interviews is one of the most important sources of data and defines the interview as a two-way conversation that gives the interviewer the opportunity to participate actively in the interview. The interview were structured and based on predetermined questions.

\section{Observation Schedule}

The researcher used lesson observation schedule during the classroom teaching of Life Skills in form two and form three to collect the primary data in four secondary schools randomly selected from the actual study sample. This enabled the researcher to observe various teaching strategies, the level of availability and adequacy of the teaching/learning resources, availability of schemes of work, lesson plans, students' participation during discussions and lesson conclusions during the lessons of life skills education in the observed classrooms in the sampled secondary schools. According to Orodho (2012), observation is one of the most important and extensively used research methods in the field of social sciences.

Piloting

Brooks (2013) and Orodho (2012) note that piloting ensures that research instruments not measure what it purports to measure but is also stable and consistent on repeated administration of the instrument. Thus, piloting enables the researcher to have meaningful observations because it helps detect deficiencies in the instruments. Through piloting, the validity and reliability of the research instrument is determined.

Validity

Validity is concerned with establishing whether the instrument content is measuring what they/it is supposed to measure (Orodho, 2009b). The researcher enhanced validity of the instruments, by employing content validity. This was done in terms of checking for items that were vague or not necessary, weaknesses of the instruments and whether respondents understood the items. The researcher also established the content 
validity by seeking his supervisors' opinion whether or not the items in the instruments were relevant Reliability

The reliability of the instruments was tested from the two piloting public secondary schools by the use of split-half method. The questionnaires for the teachers were tested on four teachers and the questionnaire for the students was tested from 24 students separately to get the correlation coefficients for each instrument. According to Orodho (2012), reliability is a measure of the degree to which a research instrument yields consistent results or data after repeated trials. The lesser the variations produced by an instrument on subsequent trials, the more reliable it is.

The Split half method for testing reliability was used. The method involves scoring two halves usually odd and even items of a test separately for each person and then calculating the correlation coefficient for the two sets (halves) of scores. The coefficient indicates the degree to which the two halves of the test provides the same results and hence describes the internal consistency of the test.

\section{Split-Half Method}

The researcher used Spearman Brown Prophecy formula:

$2 \mathrm{x}$ Corr. between the halves

$1+$ Corr. between the halves

$2 \mathrm{r}$

$\mathrm{r}=$

$$
r+1
$$

$\mathrm{r}=$ reliability of the coefficient resulting from correlating the scores of the odd items with the scores of the even items ( Orodho, 2009b, 2012).

The researcher used small identical samples not included in the final study to test on the reliability of the questionnaires for teachers and students separately. A coefficient of 0.70 is considered adequate but a coefficient of 0.80 is good according to Gay (2003). The researcher got a coefficient of 0.76 for the students' questionnaires and 0.78 from the teachers' questionnaires. The researcher, therefore, concluded that the instruments were reliable for the study.

\section{Data Collection Procedure}

A permit to collect data was obtained from the National Commission for Science and Technology (NACOSTI) to allow for data collection. The researcher made appointments with principals of the sampled schools to request them for permission to carry out the study in their schools. The researcher arranged with the principals to confirm the dates for data collection and got the consent of the school administration. This was to eliminate the cases of surprising entry into schools without prior visit to clarify the intention of the visit. The instruments were administered to the respondents who were given ample time to respond to the questions.

The researcher ensured confidentiality of the information given by the respondents. Confidentiality was to ensure respect for the dignity of participants in the study. Therefore, it was important that participants had no doubt that any identifying information provided would be regarded as confidential. Participants were informed that their confidential information provided would only be accessed by the researcher and the supervisor. They were not required to provide any identifying information such as their names, hence making responses become unanimous (Orodho, 2012).

Data Analysis

The primary quantitative data collected from the field were first edited to remove errors from responses written which were not required. Coding was done to summarize the data, where code numbers were assigned to each of the research questions. The coded items were analyzed with the aid of Statistical Package for Social Sciences (SPSS) computer software version 20 for analyzing data (Orodho, 2009b). Both quantitative and qualitative data analysis techniques were used to analyze data as per the study objectives.

\section{Data Presentation, Findings And Discussions}

\section{Teacher Training on Life Skills Education}

The study sought to determine teachers' training on Life Skills education. The study found that $80 \%$ of the teacher respondents had not attended the training while $20 \%$ had attended the training on life skills education. According to Republic of Kenya (2004; 2012), majority of secondary school teachers are trained at public universities and diploma colleges and are required to specialize in two teaching subjects upon graduation. Currently, the class sizes in universities are too large for lecturers to pay special attention to methodology and therefore the quality of the teacher is often compromised. In addition, a lot of students take education courses for lack of alternatives. In order to improve the quality of teachers graduating out of our universities, it is imperative that the secondary school teacher training programmes is restructured to enable the trainees acquire sufficient subject mastery and pedagogy. This means that secondary school teachers have not received any life 
skills education training as part of their pre-service training. The findings of the study were as presented in Figure 2.

In an interview with principals on the attendance of their teachers on training in Life Skills Education, it was found the over half of the principals interviewed indicated that teachers in their schools had not attended such trainings while about three quarters of the principals indicated that teachers in their schools had attended such trainings.

According to the principals interviewed, it was evident that:

The continuous improvement in the quality of education services for practicing teachers is currently lacking, yet should facilitate continuous skills upgrading for the teachers. They stressed that although Kenya Education Institute has been conducting some training for principals and other school managers, this has not been the case for ordinary teachers due to inadequate opportunities for in-service training. This has consequently has denied most of practicing teachers the chance to enhance their skills beyond those acquired during their pre-service basic training.

The foregoing citation indicates that the current caliber of teachers' situation calls for an urgent development of a comprehensive in- service training programmes to empower teachers to deliver the changes that have been made in the existing school curricula including the introduction of Life Skills Education in schools in 2008. From the findings of the study, it is clear that most of the teachers had not attended in-service trainings on Life Skills Education.

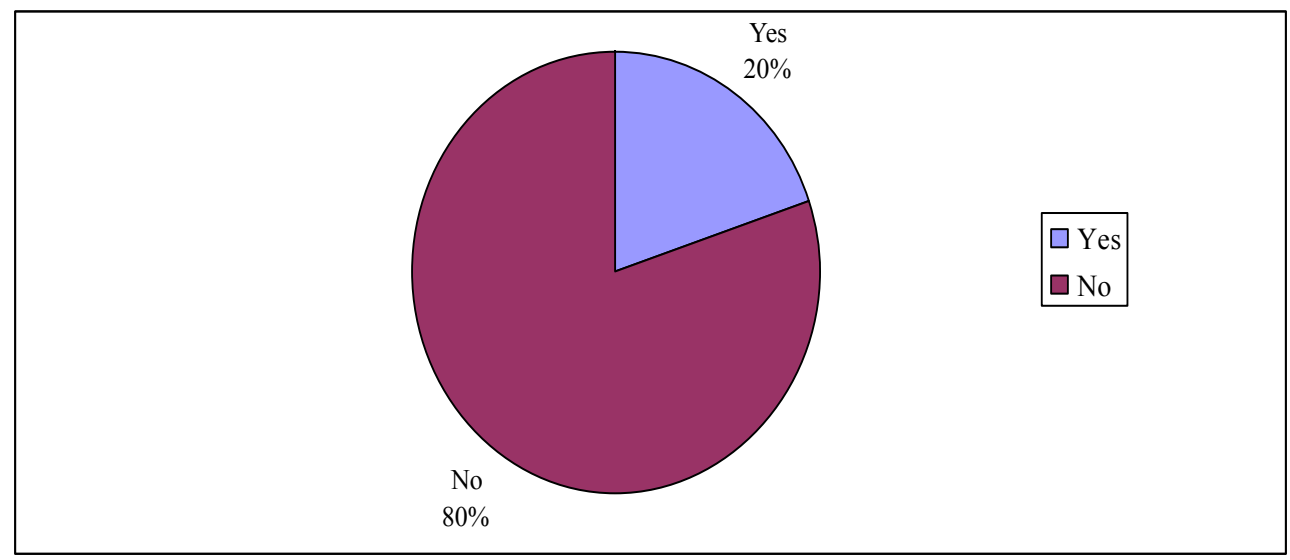

Figure 2 : Attendance on Training in Life Skills Education

The few teachers who had attended training on Life Skills Education were further asked to indicate the areas in which they were trained on. The following areas were mentioned:

pedagogy used and applied in teaching of the subject, effective decision in teaching of the subject, scouting for solution, interpersonal relationship, conflict resolution and negotiation management, and development of the society.

The citation is in tandem with Shiundu and Omulando (1992) as well as Bizimana and Orodho (2014) who concur that teachers given their vital role in curriculum implementation, they need appropriate relevant training to be able to handle a new programme including life skills education. Recent studies by Birimana and Orodho (2014) and Orodho (2013) are in agreement regarding the need for continuous staff development in order to enhance quality of curriculum implementation.

\section{Attitude on Implementation of Teaching Life Skills Education}

To determine the attitude towards implementation of life skills education in secondary schools, student respondents were asked to indicate their agreements with different statements towards implementation of life skills education in secondary schools. The findings of the study were as presented in Table 2 .

Table 2 shows that $35 \%$ of the student respondents strongly agreed that teaching of Life Skills Education in schools was not necessary because they are non-examinable. The study also found that $35 \%$ of student respondents agreed that teaching of Life Skills Education consumes time that can be used to teach other examinable subjects. Regarding the importance of life skills, it was found that $60 \%$ of the student respondents strongly agreed that teaching of life skills Education in secondary schools was very important. The study further found that $42 \%$ of the student respondents strongly agreed that content of Life Skills education was easy to understand and that teaching of Life Skills will promote awareness and enhance change behaviour as indicated by $58 \%$ student respondents. 
The finding of this study echo the sentiments of Oluoch (1982) and Bizimana and Orodho (2014) who aver that a teacher who has a positive attitude towards life skills education and uses appropriate instructional strategies is likely to influence the students develop the same attitude. The study also found that students disagreed with the statement that the aims and objectives of teaching of Life Skills Education are irrelevant and unattainable. This is an indication that students recognized the importance of Life Skills Education in their schools.

Regarding the attitude of the teachers to the teaching of Life Skills, the study found that most of the teachers had negative attitude towards the teaching of Life Skills Education. This was evidenced by the fact that many of the teachers had not been trained on the Life Skills Education. Witt (2002) argue that teaching methods are influenced by the teacher's attitude towards the teacher's competence in regard to the subject matter; a teacher uses teacher centered method which allows her full control of the class. If she/he is competent, she/he allows children to learn on their own and gives help when necessary. Grogarn (1993) adds that cultivation of positive attitude is of paramount importance to a school teacher.

Table 2 : Attitude on Implementation of Teaching Life Skills Education

\begin{tabular}{|c|c|c|c|c|c|c|}
\hline & $\begin{array}{l}\text { Strongly } \\
\text { Agree }\end{array}$ & Agree & $\begin{array}{l}\text { Neither } \\
\text { agree nor } \\
\text { Disagree }\end{array}$ & Disagree & $\begin{array}{l}\text { Strongly } \\
\text { Disagree }\end{array}$ & Total \% \\
\hline
\end{tabular}

\begin{tabular}{|c|c|c|c|c|c|c|}
\hline \multicolumn{7}{|l|}{ Statements } \\
\hline $\begin{array}{l}\text { Teaching of Life Skills in schools } \\
\text { is not necessary because they are } \\
\text { non- examinable. }\end{array}$ & 35 & 17 & 7 & 32 & 9 & 100 \\
\hline $\begin{array}{l}\text { Teaching of Life Skills consumes } \\
\text { time that can be used to teach other } \\
\text { examinable subjects. }\end{array}$ & 11 & 35 & 7 & 39 & 8 & 100 \\
\hline $\begin{array}{l}\text { Life Skills is an important subject } \\
\text { in the school curriculum. }\end{array}$ & 60 & 27 & 8 & 3 & 2 & 100 \\
\hline $\begin{array}{l}\text { Content of Life Skills education is } \\
\text { easy to understand. }\end{array}$ & 42 & 34 & 15 & 6 & 3 & 100 \\
\hline $\begin{array}{l}\text { Teaching of Life Skills will } \\
\text { promote awareness and enhance } \\
\text { change behaviour. }\end{array}$ & 58 & 25 & 10 & 3 & 4 & 100 \\
\hline \multicolumn{7}{|l|}{$\begin{array}{l}\text { Provision of teaching and learning } \\
\text { materials for Life Skills is } \\
\text { expensive but not worthwhile. }\end{array}$} \\
\hline $\begin{array}{l}\text { The aims and objectives of } \\
\text { teaching of Life Skills are } \\
\text { irrelevant and unattainable. }\end{array}$ & 15 & 10 & 10 & 62 & 11 & 100 \\
\hline
\end{tabular}

On the provision of teaching and learning materials, the study found that one third of student respondents dis-agreed that provision of teaching and learning materials for Life Skills Education is expensive but not worthwhile. The study finally found that approximately two thirds of student respondents disagreed that the aims and objectives of teaching Life Skills Education were irrelevant and unattainable.

In an interview with the principals, nearly all of them were of the opinion that:

Teachers and students do not take Life Skills Education seriously since it is not examinable. It became clear from these principals that teachers and students only take examinable subjects seriously given the examination -oriented curriculum interpretation of learning in most schools in Kenya.

The finding is strongly supported by an earlier study by Rooth (2005), in South Africa that life skills education is not being taken seriously because it is not examinable subject. Whitaker (1993), assert that assessment in the form of examination influences curriculum implementation due to the great value given to public examination certificates by schools, teachers and students tend to concentrate on subjects that are examinable and are thought to promote academic excellence.

It was further found that teachers and students had conflicting attitude towards the subject in the sense that:

Teachers had negative attitude towards the subject thus affecting its implementation in the curriculum. To the contrary, students' attitude, it was found that students take the teachings of life skills education positively especially those on how to manage their lives in a healthy and productive manner including the fight against HIV and AIDS and students are receptive as they participate by asking questions. 
The overall picture emerging is that while teachers have negative attitudes towards the teaching of life skills, the students on the other half have positive attitude towards learning LSE. The most plausible explanation is that teachers are over worked and do not see the need to exert additional energy on subjects that area not counting towards their workload. This finding is in line with Bizimana and Orodho (2014) and Orodho, Waweru, Getange and Miriti (2013) that stressed those teachers overload is making them develop negative attitude towards the teaching profession.

\section{Teaching/learning Resources for Life Skills Education}

In examining the level of availability and adequacy of various resources used in teaching Life Skills Education in secondary schools, the teacher respondents were asked to indicate the level of adequacy of various resources used in teaching Life Skills Education in their secondary schools. The findings of the study were as shown in Table 3.

Table 3: Teaching Resources for Teaching Life Skills Education

\begin{tabular}{|c|c|c|c|c|c|c|}
\hline Resources & $\begin{array}{c}\text { Very } \\
\text { adequate }\end{array}$ & Adequate & Average & Inadequate & $\begin{array}{c}\text { Not available } \\
\text { at all }\end{array}$ & $\begin{array}{c}\text { Percentage } \\
(\%)\end{array}$ \\
\hline $\begin{array}{l}\text { Charts or } \\
\text { pictures }\end{array}$ & 7 & 30 & 3 & 13 & 7 & 100 \\
\hline Magazines & 30 & 44 & 13 & 3 & 10 & 100 \\
\hline Newsletters & 20 & 33 & 20 & 17 & 10 & 100 \\
\hline Pamphlets & 40 & 23 & 7 & 23 & 7 & 100 \\
\hline Video tapes & 27 & 33 & 23 & 3 & 14 & 100 \\
\hline
\end{tabular}

Table 3 shows that charts and pictures were available and adequate as indicated by slightly less than half of teachers who said that they were very adequate and approximately one third of teacher respondents who said that they were adequate. On the availability of magazines, the study found that the magazines were adequate as indicated by nearly half of teachers who said that they were adequate and about one third of teachers who said that they were very adequate. Regarding the adequacy of newsletters, the study found that exactly one third of teachers indicated that the resources were adequate while about twenty percent of teachers who said that they were inadequate. On the adequacy of pamphlets, less than half of teachers indicated that they were very adequate. The study finally found that one third of the teacher respondents indicated that video tapes were adequate while less than $15 \%$ of teachers indicated that they were not available at all. The study found that resources such as charts and pictures, magazines, newsletters, pamphlets and video tapes were available in some schools though they were inadequate.

The findings are in line with those of Kieff et al., (2000) who aver that a class is equipped with materials that suggest activities and provide the materials needed for activities invented or initiated by students. It can be said that even though the resources for teaching Life Skills Education were available in most of the schools studied, they were not adequate. From the findings of the study, it can be said that even though the resources were available in most schools studied, some schools had none of the resources. This disproportional distribution of resources was also established by Orodho 92014) study on public secondary schools in Mandera County, Kenya.

On the whole the school principals were requested to state the extent their respective schools were prepared to teach life skills education. Majority reached a common verdict that:

Resources for teaching Life Skills Education were inadequate in their secondary schools. This implied that most school principals were of the opinion that the level of preparedness to teach LSE was too low in most schools.

The opinions of the headteachers were cross-examined using an observation checklist. The observation of the status of resources confirmed that although resources such as charts and pictures, magazines, newsletters, pamphlets and video tapes were available in some secondary schools these resources were grossly inadequate to facilitate effective teaching of life skills education. This was an indication that most secondary schools did not have enough resources for the teaching and learning of Life Skills Education.

\section{Teacher Training on Life Skills Education}

\section{Conclusions And Recommendations}

In establishing the training of teachers on Life Skills Education, the study found that most of the teachers had not been trained on Life Skills Education as indicated by $80 \%$ of the teachers interviewed. This was further confirmed with the findings from an interview with the principals where over half of the principals indicated that teachers in their schools had not attended such trainings. Those who had attended the trainings on Life Skills Education were trained on, interpersonal relationship, conflict resolution and negotiation management, importance of Life Skills Education, living values and on methodologies for teaching Life Skills Education. 


\section{Teachers' and Students' Attitudes}

With regards to the attitudes of students and teachers towards lif skills education, it was found that students had positive attitude towards the teaching of Life Skills Education in schools. On the other hand, it was found that teachers had negative attitude towards teaching of life skills Education due to the fact that it was not examinable and had not trained on life skills education thus affecting its implementation in secondary schools. This was evidenced by the fact that over half of the students agreed with the statements that teaching of Life Skills Education will promote awareness and enhance behaviour change and that the content of Life Skills education is easy to understand. It was also found that nearly two thirds of the students disagreed with the statement that the aims and objectives of teaching of Life Skills Education are irrelevant and unattainable. This is an indication that students recognized the importance of Life Skills Education in their secondary schools, while the teachers were not as enthusiastic as expected. This finding confirms that the teaching of life skills education still hangs on the balance.

\section{Availability and Adequacy of Resources for Teaching and Learning of LSE}

The study found that resources such as charts and pictures, magazines, newsletters, pamphlets and video tapes were available in some schools though they were inadequate, especially for the teaching of life skills education. Other resources that were available included: peer counselors, resource persons, textbooks, radio tapes, radio programmes, organizing drama among students and theatre. It can be said that even though the resources for teaching Life Skills Education were available in most secondary schools studied, but they were not adequate.

\section{Conclusions and Recommendations}

The thrust of this study was to examine the level of preparedness of teachers and school managers in implementing life skills education. Regarding teachers' and students attitudes towards teaching of Life Skills Education in secondary schools, it was concluded that teachers have negative attitude towards the teaching of Life Skills Education on the basis that most of them have not been trained on Life Skills Education and because life skills education is not examinable subject. Students are perceived to have positive attitudes towards the teaching of Life Skills Education as evidenced by their participation through asking questions and discussions during the teaching of life skills education in secondary schools.

On the level of availability and adequacy of resources for teaching and learning of Life Skills Education, the study concluded that most of the secondary schools studied had resources such as: charts and pictures, magazines, newsletters, pamphlets and video-tapes, but they were inadequate. The cumulative evidence has revealed that most schools are not yet prepared to implement life skills education in their respective schools.

From the findings and conclusions made, the following recommendations are made:

First, since most of the teachers were not trained, it was recommended that teachers should be trained on Life skills Education in teacher training colleges. Teachers in the field should also attend in-service training on Life Skills Education, seminars and workshops where they can get acquainted with the relevant knowledge and skills which are necessary for their and guidance roles to their students.

Secondly, since most of the teachers had negative attitude towards life skills education, it was recommended that teachers should be encouraged change their attitude towards the teaching of Life skills Education in secondary schools. By viewing the teaching of life skills education positively, teachers will be motivated to impart life skills into students. Teachers' negative attitude towards Life Skills Education should be considered before allocating Life Skills Education to teachers. There is need to review the tradition of schools of teachers taking up the teaching of Life Skills Education because they are C.R.E and Biology teachers and are expected to teach it. It should be assigned to teachers who have some interest in the subject.

Third, Life Skills Education should be examinable so that students and teachers take it seriously like other examinable subjects in the school curriculum. By making it examinable, the teachers and students would put more mental energy in LSE.

Finally, since it was established that the status of resources was in a soory state in some schools, it is recommended that:

a. The government through the Ministry of Education should provide adequate resource materials as such text books, teaching aids and stationery in order to enable teachers implement life skills education effectively.

b. Teachers should improvise teaching aids for teaching and learning of Life Skills Education in their secondary schools.

c. Schools should also supplement the teaching and learning materials for successful implementation of life skills education by either buying or sourcing them from the environment, locally made, borrow or share at departmental or inter-school levels. 


\section{References}

[1]. Bandura, A. (1986). Social foundations of thought and action: a social cognitive theory. In Bartholomew et al. (2001) .

[2]. Bunyi, W. G. (2000). Girls' education: An annotated bibliography on 13 AGEI countries in Eastern and Southern Africa. Nairobi: UNICEF.

[3]. Bizimana, B., Orodho,A.J..(2014). Teaching and learning resource availability and teachers effective classroom management and content delivery in secondary schools in Huye District, Rwanda. Journal of Education and Practice.Vol.3.No.9. pp111122.www.iiste.org

[4]. Brook,.S.E.(2013). Selecting a sample. Educational Research, 250.

[5]. Cronin, M. (1996). Life skills curricula for students with learning disabilities: A review of the literature. Journal of Learning Disabilities, 29(1), 53-68.

[6]. Gay, R. L. (2003). Educational research: Competencies for analysis and application (7 $7^{\text {th }}$ ed) Columbus: Charles E. and Merrill Publishing Company.

[7]. Githinji, F.W. (2007). Perceptions of school teachers and pupils on adequacy of HIV/AIDS life skills education. Nairobi and Thika Districts, Kenya. Unpublished M.Ed Thesis. Nairobi, Kenyatta University.

[8]. Jansen, J. (2002). Image-inning Teachers: Policy Images and Teacher Identity in South African classrooms. In K. Lewn. M. Samwel and Y. Sayed (eds. ) Changing patterns of Teacher Education in South Africa: Policy, practice and prospects. Sandown: Heinemann. [9]. Jansen, J. (2008). Behavior of Learners. In Saturday Star. 14 April. 2008.

[10]. Kadzamira, E.C. (2006). Teacher Motivation and incentives in Malawi. Zombie centre for Research and Training.

[11]. KIE, (1999). Guidelines for early childhood development in Kenya. NACECE. Nairobi: KIE.

[12]. Kieff, J.E. \& Casbergue, R.M. (2000). Playful learning and teaching integrated play into pre-school and primary programs. University of New Orleans.

[13]. Koech, D. K.(1999). Totally intergrated quality education and training TIQET. Report of the Commission of Inquiry into the Education System of Kenya. Nairobi: Government Printer.

[14]. Kothari C. R. (2003). Research methodology: Methods and techniques. New Age International. New Delhi: (P) Limited publishers.

[15]. Krilik, B. (2008). Values Teaching. http: // www. Ust. Hk/ career/ files/ value- edu. Doc

[16]. Mahlangu, T. P. (2001). Challenges facing the implementation of curriculum 2005 (c2005) in Mpumalanga Witbank District. Unpublished Masters' research, university of Withwatersrand, Johanesburg.

[17]. Oluoch, G.P. (1982). Essentials of curriculum development. Nairobi: Elimu Bookshop.

[18]. Ornstein, A. C. \& Hankins, F. (1993). Curriculum: Foundations, Principals, and Theory. Boston: Allyn and Bacon.

[19]. Orodho, A.J. (2009a). Elements of Education and Social Science Research Methods: Maseno, Kenya: Kanezja Publishers.

[20]. Orodho, A.J. (2009b). Techniques of Data Analysis Using Statistical Package for Social Sciences (SPSS) Computer Package. Maseno, Kenya: Kanezja Publishers.

[21]. Orodho, A.J. (2012). Techniques of Writing Research proposals in Education and Social Sciences (: Maseno, Kenya: Kanezja Publishers.

[22]. Orodho, A.J.(2014).The equity and quality of free day secondary education (FDSE) Policy in Kenya: What is the unfinished business in the financial management. .International Journal of Current Research. Vol.8. Issue 03(March, 2014) 5582-5591. http://www.journalcra.com.

[23]. Orodho, A.J, Waweru, P.N, Ndichu.,\& Nthinguri.(2013).Basic education in Kenya: Focus on strategies applied to cope with schoolbased challenges inhibiting effective implementation of curriculum. International Journal of Education and Research. Vol 1.No.11 November, 2013 pp1-10.www.ijern.com.

[24]. Orodho, A.J., Waweru, P.N., Getange,K.N \& Miriti, J.M.(2013).Progress towards attainment of education for All (EFA) among nomadic pastoralists : Do home-based variables make a difference in Kenya? Research on Humanities and Social Sciences. Vol3.No.21, 2013 pp54-67.www.iiste.org .

[25]. Republic of Kenya, (2005). A Policy Framework for Education, Training and Research: Meeting the Challenges of Education, Training and Research in Kenya in the 21 st Century. Nairobi: MoES\&T.

[26]. Republic of Kenya. (2005a).) Sessional Paper No. 1 on Policy Reforms for Education, Training and Research: Meeting the Challenges of Education Training and Research in the $21^{\text {st }}$ Century. Ministry of Education, Science and Technology (MOEST Nairobi: MOEST.

[27]. Republic of Kenya(2005b). Kenya Education Sector Support Programme 2005 - 2010: Delivering Quality Education and Training to All Kenyans. Nairobi: MOEST.

[28]. Republic of Kenya.(2012a).Sessional Paper No.14 of 2012 on realigning education and training to the Constitution of Kenya 2010 and Vision 2030 and beyond. Ministry of Education Science and Technology. Nairobi. Kenya.

[29]. Republic of Kenya.(2012b).A Policy Framework for re-aligning education to the Constitution 2010 and Vision 2030 and beyond.

[30]. Republic of Kenya.(2013). The Basic Education Act, 2013 No 14 of 203.The Government Press, Nairobi.

[31]. Republic of Kenya/UNICEF( 2012).Education for All (EFA) End of Decade Assessment (2001 -2010). Ministry Of Education and INICEF. Nairobi.

[32]. Parsons, C, Hunter, D. \& Warne, Y. (1988). Skills for adolescence: An analysis of project material, training and implementation. Canterbury. Christ Church, College UK. Evaluation Unit.

[33]. Prinsloo, D.J. (2007). Implementation of Life Orientation Programmes in the new Curriculum in South African Schools: Perceptions of principals and life orientation teachers South African Journal of Education Vol 27 (1). 155-170

[34]. Republic of Kenya (2004). Sessional Paper: On A Policy Framework for Education, training and Research. Nairobi: Government Printer.

[35]. Rooth, E. (2005). An investigation of the status and practice of Life Orientation in South African schools in two provinces. Unpublished PhD Thesis, University of Western Cape, Cape Town.

[36]. Pratt, D. (1980). Curriculum Design and Development. Harcourt: Brace Jovanorich inc.

[37]. Shiundu, J. S. \& Omulando, S. J. (1992). Curriculum theory and practice in Kenya. Nairobi: OUP.

[38]. Singleton,M. (1973). Teaching Mathematics. London New York: Routledge.

[39]. Thurstone, L.L. (1931). The measurement of attitudes. In Journal of Abnormal and Social Psychology.

[40]. UNICEF). (2002). The state of the world's children's 2000. New York: UNICEF.

[41]. Wiersma, W. (1980). Research methods in education. An introduction ( ${ }^{\text {rd }}$ Ed.). Illinois: F.E Peacok Publishers, Inc.

[42]. WHO. (1997). Life skills education for children and adolescents in schools. Programme on Mental Health. Geneva. Programmes on Mental Health. Geneva.

[43]. WHO). (2001). Life skills education for children and adolescents in schools. Programme on Mental Health. Geneva. Programmes on Mental Health. Geneva. 